\title{
High sensitive sol-gel based electrochemical immunosensor for Clenbuterol Determination
}

\author{
Benle Zhan, Yeting Zhang, Xiang Zhao* \\ College of Physical Education, Chengdu University, Chengdu 610106, China \\ "E-mail: xiangzhaollz@sina.com
}

Received: 31 July 2021 / Accepted: 9 September 2021 / Published: 10 October 2021

Clenbuterol is a class of sympathomimetic agents that are used clinically to treat asthma and bronchospasm. It also has physiological effects similar to those of metabolic steroids to promote the growth of muscle tissue, and is therefore abused in animal husbandry to improve lean muscle mass. It is also used as an agonist that has been banned in sports. In this work, a sensitive electrochemical immunosensor was constructed by modifying $\mathrm{ZnO}$ nanoparticles and clenbuterol onto the electrode surface using sol-gel method with clenbuterol being the detection target. Under the optimized experimental conditions, the immunosensor showed a wide linear range and low detection limit. The working linear range was 0.3 to $1000 \mathrm{ng} / \mathrm{mL}$, and the detection limit was $0.12 \mathrm{ng} / \mathrm{mL}$. Meanwhile, this immunosensor is simple, rapid, reproducible and stable. In addition, the above sensor has a good accuracy and immunity to interference in the detection of animal feed samples.

Keywords: Clenbuterol; Immunosensor; Sol-gel; Doping; ZnO

\section{FULL TEXT}

(C) 2021 The Authors. Published by ESG (www.electrochemsci.org). This article is an open access article distributed under the terms and conditions of the Creative Commons Attribution license (http://creativecommons.org/licenses/by/4.0/). 